\title{
a-Mangostin dari Buah Manggis, Kandidat Obat Antikanker Baru
}

\author{
Agus Rusdin \\ Program Studi Magister Farmasi, Fakultas Farmasi, Universitas Padjadjaran, Sumedang, Jawa Barat. \\ email: agusrusdin@gmail.com \\ (Submit 22/6/2019, Revisi 16/7/2019, Diterima 18/7/2019)
}

\begin{abstract}
Abstrak
Kulit buah manggis memiliki banyak manfaat dalam mengobati berbagai penyakit. Ekstrak dari kulit buah ini telah diuji memiliki aktivitas sebagai antikanker dengan nilai pengambatan $50 \%$ kurang. a-mangostin dari kulit manggis telah terbukti memiliki berbagai efek farmakologis diantarnya adalah antioksidant, antiinflamasi, antinyeri, antialergi, antifungi, antibakteri, antiobesitas, antiparasit, antituberkolosis, Alzheimer, dapat meningkatkan sistem imun, dan sebagai anti kanker. Dalam mini review artiken ini didiskusikan terkait bukti-bukti ilmiah anti kanker dari a-mangostin.
\end{abstract}

Kata kunci : a-mangostin, kanker, buah manggis

\section{Outline}

- Pendahuluan

- Buah manggis

- a-Mangostin

- Aktivitas Antikanker a-Mangostin

- Uji Toksisitas a-Mangostin

- Kesimpulan

- Daftar Pustaka

\section{Pendahuluan}

Manggis merupakan tumbuhan asli indonesia yang secara turun temurun telah dimanfaatkan buahnya sebagai bahan makanan yang memiliki rasa yang enak dan kaya akan kandungan antioksidan nya.

\section{Buah manggis}

Buah manggis sering dijuluki The queen of tropical fruit. Bagian-bagian lain dari tumbuhan manggis seperti (akar, batang dan daun) diketetahui juga memiliki manfaat sebagai anti bakteri, anti jamur, malaria dan juga sering dimanfaatkan untuk mengobati berbagai penyakit degeneratif.

Selain memiliki daging buah yang enak dan sehat, ternyata kulit buah manggis juga memiliki banyak manfaat dalam mengobati berbagai penyakit. Ekstrak dari kulit buah ini telah diuji memiliki aktivitas sebagai antikanker dengan nilai pengambatan 50\% kurang 


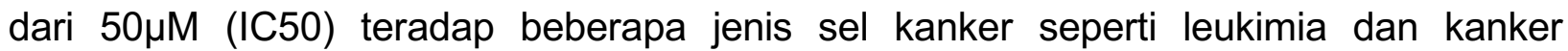
payudara. Hal ini menjadi daya tarik para ilmuan untuk melakukan uji lebih lanjut terkait senyawa spesifik yang berperan dalam aktivitas antikanker.

\section{a-Mangostin}

a-mangostin merupakan senyawa turunan xanton dengan nama kimia (1,3,6 trihidroksi -7 - metoksi - 2, 8 - bis (3 metil - 2 - butenil) - 9H-xanten-9-0n), Merupakan senyawa metabolit sekunder yang di isolasi dari ekstrak kulit manggis. amangostin telah terbukti memiliki berbagai efek farmakologis diantarnya adalah antioksidant, antiinflamasi, antinyeri, antialergi, antifungi, antibakteri, antiobesitas, antiparasit, antituberkolosis, Alzheimer, dapat meningkatkan sistem imun, dan sebagai anti kanker.

\section{Aktivitas Antikanker $\alpha-M a n g o s t i n$}

Besarnya prevalensi kasus penyakit kanker di dunia, menempatkan penyakit ini berada di urutan kedua setelah penyakit kardiovakular sebagai penyakit yang paling mematikan.

Pengobatan yang cenderung memiliki banyak keterbatasan seperti efek samping seperti kerusakan organ pada terapi pembedahan, kematian sel normal pada terapi radiasi dan efek samping lainnya pada kemoterapi menjadi perhatian utama dalam bidang keseatan.

Para ilmuan mencari berbagai solusi baik itu pengembangan bentuk sediaan obat, modifikasi fisika agen kemoterapi hingga upaya pencarian agen agen baru dari alam yang memiliki efektivitas yang lebih baik dan toksisitas yang lebih rendah.

a-Mangostin merupakan salah satu senyawa yang paling sukses ditemukan sebagai kandidat obat antikanker baru, disamping memili aktivitas antikanker yang bagus senyawa ini telah telah diuji keamanannya pada sel normal.

Aktivitas antikanker dari a-mangostin telah dilakukan pada berbagai jenis jenis sel kanker baik itu secara invitro atau invivo, hasil yang mengesankan diperoleh dimana $\alpha-$ tangostin menunjukan penghambatan yang maksimal pada konsentrasi $10 \mu \mathrm{M}$ dan mampu menginduksi apoptosis sel atau kematian sel terprogram pada leukimia cell line (HL60), selain itu pada uji invivo yang dilakukan pada tikus menunjukan $\alpha$-tangostin memiliki efek kemopreventif pada karsinogenesis colon, a-tangostin juga mampu menginduksi apoptosis pada sel kanker pancreas (PCL12), kanker kolon (DLD-1), kanker payudara (BC- 1, MCF-7, MDA-MB-231), epidermoid carcinoma (KB), kanker paru-paru (A549), head and neck squamous cell carcinoma (HNSCC), human melanoma (SK-MEL-28) cell line, mammary cancer, kanker tulang (canine osteosarcoma D-17), colorectal carcinoma (HCT- 116), mampu menghambat metastasis kanker prostat $(\mathrm{Pc}-3)$, dan berbagai sel kanker lainnya melalui berbagai jalur (multiple pathways) seperti jalur mitokondria, signalisasi JNK, regulasi gen $\beta$ catenin pada jalur Wnt/cGMP, AKT/PI3K, MAPK, signalisasi avß3 Integrin/FAK/ERK dan NF-kB. 
Kita bisa melihat dari penjelasan sebelumnya bahwa potensi a-mangostin dalam menangani penyakit kanker tidak perlu diragukan lagi, selain memiliki sitotoksisitas yang kuat, senyawa ini bekerja dengan berbagai mekanisme yang memungkinkan memiliki aktivitas pada semua sel kanker.

Selanjutnya jika mempertimbangkan masalah masalah atau keterbatasan yang telah diuraikan sebelumnya terkait masalah terapi yaitu efek samping yang mungkin dapat ditimbulkan oleh agen anti kanker, disinilah titik perbedaan yang dimiliki ole senyawa $\alpha$ mangostin ini, dimana senyawa ini terbukti aman teradap sel normal dan hanya reaktif pada sel-sel kanker.

Hal ini telah dibuktikan dari uji-uji toksisitas yang telah dilakukan yang akan d uraikan pada bahasan selanjutnya.

\section{Uji Toksisitas $\alpha-M a n g o s t i n$}

Uji toksisitas a-mangostin untuk melihat seberapa aman senyawa ini untuk makhluk hidup telah dilakukan secara in vivo menggunakan model mencit, hewan uji diberikan beberapa variasi dosis $\alpha$-mangostin $(5,10,20,50,100,200$ dan $500 \mathrm{mg} / \mathrm{kg})$ secara intraperitoneal.

Dari pengujian ini diperoleh nilai LD50 (150 mg/kb). dari 6 ekor mencit dalam satu kelompok uji menujukan tidak ada satupun mencit yang mati pada pemberian $20 \mathrm{mg} / \mathrm{kg}$ dan hanya ad satu mencit yang mati pada kelompok pemberian $50 \mathrm{mg} / \mathrm{kg}(7.7 \%$ mortality) (Choi et al., 2014), pada pengujian lainnya dilakukan oleh (Verma et al., 2016) amangostin dijadikan sebagai control untuk formulasi nanopartikel yang mereka buat, pada pengujian proliferasi sel menggunakan sel kanker pancreas (CSCs) dan sel normal human pancreatic normal ductal epithelial (HPNE), dari pengujian ini, $\alpha$-mangostin

memberikan efek penghambatan pada sel kanker dan tidak berefek pada sel normal, hal ini mengindikasikan bahwa a-mangostin aman terhadap sel normal.

\section{Kesimpulan}

Berdasarkan uraian diatas, dapat disimpulkan bahwa a-mangostin memiliki potensi anti kanker yang kuat dan memiliki spectrum yang luas terhadap berbagai jenis sel kanker, selain itu juga memiliki toksisitas yang rendah pada sel normal, hal ini menjadi salah satu peluang yang sangat baik untuk menutupi masalah terapi saat ini yang kita ketahui bersama bahwa agen agen kemoterapi memiliki banyak efek samping yang merugikan terhadap sel yang sehat.

Hal ini mejadikan a-mangostin sebagai candidat obat antikanker baru yang wajib dan yang benar-benar perlu di realisasikan untuk meningkatkan derajat kesehatan dan harapan hidup banyak orang. 


\section{Daftar Pustaka}

Aisha, A., Abu-Salah, K., Ismail, Z., Abdul, M.A., 2012. in vitro and in vivo anti-colon cancer effects of Garcinia mangostana xanthones extract. BMC Complement. Alternat. Med. 12, 104-112.

Hung, S.H., Shen, K.H., Wu, C.H., Liu, C.L., Shih, Y.W., 2009. aMangostin suppresses PC3 human prostate carcinoma cell metastasis by inhibiting matrix metalloproteinase-2/9 and urokinaseplasminogen expression through the JNK signaling pathway. J. Agric Food Chem. 57, 1291-1298.

Baca : Peneliti Temukan Vaksin Kanker Baru yang Bisa Sembuhkan Tumor Ibrahim, Mohamed Yousif, Najihah Mohd Hashim, AbdalbasitAdam Mariod, Syam

Mohan, Mahmood Ameen Abdulla, Siddig Ibrahim Abdelwahab, and Ismail Adam Arbab. " $\alpha-M a n g o s t i n$ from Garcinia mangostana Linn: an updated review of its pharmacological properties.” Arabian journal of Chemistry 9, no. 3(2016): 317-329.

Kaomongkolgit, R., Chaisomboon, N., Pavasant, P., 2011. Apoptotic effect of alphamangostin on head and neck squamous carcinoma cells. Arch. Oral Biol. 56, 483-490

Krajarng, A., Nilwarankoon, S., Suksamrarn, S., Watanapokasin, R., 2012. Antiproliferative effect of a-mangostin on canine osteosarcoma cells. Res. Vet. Sci. 93, 788-794. 